\title{
Econometric Analysis of Radiata Pine Log Trade between New Zealand and East Asian Countries
}

\author{
Tetsuya MICHINAKA (Yufu ZHANG) ${ }^{1,4 *}$, Satoshi TACHIBANA ${ }^{2,5}$ and \\ James A. TURNER ${ }^{3,6}$ \\ ${ }^{1}$ Department of Forest Policy and Economics, Forestry and Forest Products Research Institute \\ (FFPRI) (Tsukuba, Ibaraki 305-8687, Japan) \\ ${ }^{2}$ Hokkaido Research Center, FFPRI (Sapporo, Hokkaido 062-8516, Japan) \\ ${ }^{3}$ People and Communities, Scion (Rotorua 3010, New Zealand)
}

\begin{abstract}
There is an increasing interest in the sustainable supply of wood from New Zealand's plantation forests. This is due to the importance of New Zealand in global trade and uncertainty about the sustainability of supply from other countries, such as Russia. The aim of this paper is to identify important factors that influence log supply and demand for New Zealand and its key Asian markets (South Korea, Japan and China). To this end we used annual time series data from 1990 to 2008 to estimate export supply and import demand functions by two stage least squares with stepwise regression estimation. We found that New Zealand's log exports to Japan and South Korea are not sensitive to price, but exports to China are sensitive to price, while New Zealand's total harvest has a stronger influence on log export supply to China and South Korea. New Zealand's domestic log consumption competes with exports to Japan, but does not compete with supply to South Korea or China. Import demand in South Korea, Japan, and China for New Zealand logs is negatively affected by import price, with Japan's import demand the most price-sensitive. The three markets differ in the impact of gross domestic product on import demand. Gross domestic product has a strong positive impact on log demand in Japan and China, but a modest impact in South Korea.
\end{abstract}

Discipline: Forest product trade

Additional key words: China, export supply function, import demand function, Japan, South Korea

\section{Introduction}

The sustainable supply of wood from New Zealand's plantation forests is receiving increasing attention. This is due to a number of factors: growing global wood consumption, recognition of the importance of wood supply from plantation forests, and increasing demand for biodiversity protection, particularly in natural forests ${ }^{30}$. Global supply from natural forests, particularly in Asia and North America, is predicted to decline, with this supply being replaced by increased harvests from plantation forests ${ }^{20,21,29,18,30}$.

New Zealand's forest products sector is almost en- tirely based on wood sourced from plantation forests, managed in a sustainable manner, following national laws ${ }^{6,1}$. Over $50 \%$ of New Zealand's plantation forest area is certified by the Forest Stewardship Council (FSC) ${ }^{6}$. New Zealand exports a large quantity of its forest products. In 2008, New Zealand was the largest supplier of $\operatorname{logs}$ to South Korea (hereafter, Korea), the third largest to Japan, and the third largest to China. Other exporters to these markets, such as Russia and Malaysia, face restrictions on their export supply. Russia has announced an increase in its $\log$ export tax to $80 \%$ by $2009^{4}$, which is predicted to lead to a $50 \%$ reduction in log exports by $2020^{26}$. Now this decision has been delayed by Russian government. Under Malaysia's policy of sustainable forest man-

\footnotetext{
Present address:

${ }^{4}$ REDD Research and Development Center, FFPRI (Tsukuba, Ibaraki 305-8687, Japan)

${ }^{5}$ Graduate School of Life and Environmental Sciences, University of Tsukuba (Tsukuba, Ibaraki 305-8572, Japan)

${ }^{6}$ Ruakura Research Centre, AgResearch (Hamilton 3240, New Zealand)

*Corresponding author: email zhangyf@affrc.go.jp

Received 17 December 2009; accepted 19 January 2011.
} 
agement and the Ninth Malaysia Plan (2006-2010), the government of Malaysia expects log output to decline gradually to 19.6 million $\mathrm{m}^{3}$ by $2010^{27}$.

The purpose of this paper is to identify key economic influences on the supply of logs from New Zealand's plantation forests and demand for these logs in New Zealand's Asian markets: Korea, Japan, and China. The next section reviews previous studies of log export supply from New Zealand and import demand in its log export markets. This is followed by a description of model estimation: data, export supply and import demand functional specification, and estimation. A discussion of results is then presented, finishing with conclusions regarding important influences on export supply and import demand for New Zealand logs.

\section{Review of previous studies}

Demand for New Zealand logs is dominated by Korea, Japan, and China, which together accounted for $87 \%$ of New Zealand's US\$722 million log exports in 2008 (WTA 2009). These markets are predicted to continue to strongly influence the future of New Zealand's log export sector ${ }^{9}$. Katz ${ }^{9}$ appears to be the only assessment of country-specific influences on demand for New Zealand logs in different market segments of China, Korea, and Japan. Attempts to identify influences on New Zealand's log exports have focused on the gap between wood supply and estimates of domestic processing capacity ${ }^{16}$. The influence of price and demand in export markets has received relatively little attention.

Econometric analysis of influences on demand for New Zealand logs in Korea, Japan, and China have been carried out by $\mathrm{Katz}^{8,10}$ and reported in Turner et al. ${ }^{5}$, Youn $^{34}$, Tomberlin ${ }^{22}$, and Buongiorno et al. ${ }^{2}$ (Table 1). These studies found price to be an important influence on demand, along with the price of logs from competing exporters, and end-use activity, such as gross domestic product (GDP) and housing starts. New Zealand's log supply was found to be influenced by price and forest in- ventory. Table 2 shows the elasticities for the influence of these factors on log supply and demand estimated from the above studies. The elasticities describe the percentage change in supply or demand due to a $1 \%$ increase in the influencing variable ${ }^{28}$.

Youn $^{34}$ estimated demand and supply equations for a model of Korean demand for radiata pine logs. The model was used to simulate the effects of Korean and international forest policy on the Korean forest sector. Korean domestic demand and supply equations were estimated separately from annual time-series data (1970-1997) using ordinary least squares (OLS). The separate estimation of demand and supply equations assumed that Korean domestic demand and supply are small enough that they do not affect international prices ${ }^{24}$. The econometric equations related coniferous timber demand to price and GDP, with price negatively affecting demand and GDP having a positive effect (Table 2). Similar to Katz ${ }^{10}$, Youn $^{34}$ found that Korean log demand was moderately affected by price and end-use activity, with the estimated elasticities being inelastic.

Tomberlin $^{22}$ estimated econometric equations for Pacific Rim country forest product demand and supply, and implemented these in the spatial equilibrium Global Forest Products $\mathrm{Model}^{2}$. The model was used to assess the impact of U.S. timber harvest restrictions in the 1990s on the region's forest sector. Log supply equations for each country were estimated using panel data, with price and forest inventory elasticities of supply being positive and inelastic (Table 2).

$\mathrm{Katz}^{8,10}$ referenced in Turner et al..$^{25}$ estimated econometric supply and demand equations for use in a model of New Zealand radiata pine logs and sawn timber supply and markets: the Radiata Pine Market Model (RPMM). The equations were estimated from quarterly time-series data using two stage least squares. New Zealand's domestic and export log supply were functions of price, with export supply being more responsive to price changes than domestic supply ${ }^{10}$ (Table 2). The RPMM includes demand relations for seven major log markets: domestic

Table 1. Summary of econometric analysis of Pacific region log supply and demand

\begin{tabular}{llll}
\hline \hline Study & Region & Data & Estimation Method \\
\hline Katz (1988) & Pacific Rim & time-series, 1966-1983 & 2SLS, 3SLS \\
Youn (1998) & Korea & annual time-series & OLS \\
Tomberlin (1999) & Pacific Rim & annual panel data & random effects \\
Katz (2006) & Pacific Rim & quarterly time-series, 1998-2005 & 2SLS \\
\hline
\end{tabular}

$2 \mathrm{SLS}=$ two-stage least squares, OLS $=$ ordinary least squares. 
pruned and unpruned, Japanese packaging and plywood markets, Korea, China, and other countries consuming New Zealand radiata pine. In the RPMM, demand for logs by New Zealand domestic consumers and foreign consumers is a function of log price. Demand for New Zealand logs by Japan and China is influenced by log price, the price of substitutes (i.e., logs from other sources such as Russia, and South and North America), and enduse activity (GDP in China, and industrial production and softwood plywood production in Japan). Log demand in Korea is a function of price and end-use activity (GDP and dwellings constructed) (Table 2). Compared with other countries, China's log demand was found to be more responsive to changes in the price of logs and substitutes, and end-use activity.

\section{Equations, data and methods}

Estimation of export supply and import demand equations requires selection of the appropriate explanatory variables and functional form. These are informed by economic theory and past empirical studies (Table 1), as well as being influenced by the availability of data ${ }^{24}$.

\section{Export Supply Equations for New Zealand's Log Exports to Korea, Japan, and China}

Assuming that exporters' objective is to maximize profits, New Zealand's log export quantity is expected to be an increasing function of the price of export logs and a decreasing function of the cost of production ${ }^{28}$. Additionally, export quantity may also be determined by New Zealand's log production capacity ${ }^{15}$. Because export quantity may not respond immediately to current export log prices but rather past prices, lagged export log prices were also included in the log export supply equation.

New Zealand's log export quantity to an individual market is further influenced by the price of export logs in other New Zealand markets and New Zealand's domestic demand for logs. These combined assumptions and scarce data led to the following empirical equation of New Zealand's log exports to Korea, Japan, and China:

$$
\begin{aligned}
& X_{i t}=\alpha_{1}+\alpha_{2} \ln \left(\frac{P_{i t}^{X}}{I_{t}}\right)+\alpha_{3} \ln \left(\frac{P_{i t-1}^{X}}{I_{t-1}}\right)+ \\
& \sum_{j} \alpha_{j} \ln \left(P_{j t}^{X}\right)+\alpha_{4} \ln \left(H_{t}\right)+\alpha_{5} \ln \left(Y_{t}\right)+\varepsilon_{i t}
\end{aligned}
$$

where $X_{i t}$ is the quantity of logs exported to country $i$ in year $t, P_{i t}^{X}$ is the price of New Zealand's log exports to country $i, I_{t}$ is an index of the price of all other goods and services used to produce export logs, which in this study was proxied by the New Zealand GDP deflator, $P_{j t}^{X}$ is the price of New Zealand's log exports in alternative export markets ( $j$ is one of the remaining two countries after $i$ has been designated to be one of these countries: Korea,

\begin{tabular}{|c|c|c|c|c|c|c|}
\hline & Country & Destination & Variable & $\begin{array}{c}\text { Youn } \\
(1998)^{+}\end{array}$ & $\begin{array}{c}\text { Tomberlin } \\
(1999)^{+}\end{array}$ & $\begin{array}{c}\text { Katz } \\
(2006)^{\circ}\end{array}$ \\
\hline \multirow[t]{4}{*}{ Supply } & New Zealand & Domestic & Price & & 0.7 & 0.2 \\
\hline & & & Inventory & & 0.6 & \\
\hline & & Export & Price & & & 1.6 \\
\hline & & & Inventory & & & \\
\hline \multirow[t]{10}{*}{ Demand } & New Zealand & & Price & & & -0.3 \\
\hline & & & End use activity & & & \\
\hline & Korea & & Price & -0.4 & & -0.7 \\
\hline & & & End use activity & 0.6 & & 0.4 \\
\hline & China & & Price & & & -1.8 \\
\hline & & & Substitute & & & 6.8 \\
\hline & & & End use activity & & & 3.0 \\
\hline & Japan & & Price & & & -0.8 \\
\hline & & & Substitute & & & 0.7 \\
\hline & & & End use activity & & & 0.6 \\
\hline
\end{tabular}

Table 2. Elasticity estimates for log supply and demand from econometric analysis of Pacific region countries

${ }^{+}$: constant elasticity for coniferous sawlogs, ${ }^{\circ}$ : elasticity calculated for sample median. 
China, and Japan $)^{\dagger}, H_{t}$ is log production capacity, which in this study was proxied by New Zealand's harvest volume, $Y_{t}$ is New Zealand's real GDP, used as a proxy for New Zealand's domestic demand for $\operatorname{logs}$, and $\varepsilon_{i t}$ is an error term. According to economic theory ${ }^{28}$, elasticities $\alpha_{2}$, $\alpha_{3}$, and $\alpha_{4}$ are expected to be positive, and $\alpha_{\mathrm{j}}$ and $\alpha_{5}$ are expected to be negative. The export supply equations for New Zealand $\operatorname{logs}$ to Korea, Japan, and China were estimated separately.

\section{Import Demand Equations for New Zealand Logs by Korea, Japan, and China}

Assuming cost minimization under a generalized Cobb-Douglas production function with constant returns to scale leads to the derived demand for imports for each country as a function of the price of import logs and quantity of output utilizing import $\operatorname{logs}^{28,5,24}$. Because import quantity may not respond immediately to current import log prices but rather past prices, lagged import log prices were also included in the log import demand equation.

Log import quantity by an individual market is further influenced by the price of logs imported from other countries. These combined assumptions and scarce data led to the following empirical equation for imports of New Zealand logs by Korea, Japan, and China:

$$
\begin{aligned}
& M_{i t}=\beta_{1}+\beta_{2} \ln \left(\frac{P_{i t}^{M}}{I_{i t}}\right)+\beta_{3} \ln \left(\frac{P_{i t-1}^{M}}{I_{i t-1}}\right)+ \\
& \sum_{j} \beta_{j} \ln \left(P_{j t}^{M}\right)+\beta_{4} \ln \left(Y_{i t}\right)+u_{i t}
\end{aligned}
$$

where $M_{i t}$ is quantity of log imports from New Zealand by country $i$ in year $t, P_{i t}^{M}$ is the price of New Zealand's $\log$ imports in country $i, I_{i t}$ is an index of the price of all other goods and services used in production of the output utilizing imported logs, which in this study was proxied by the country GDP deflator, $P_{j t}^{M}$ is the price of log imports from other sources, and $Y_{i t}$ is production output in the importing country, proxied by the country's real GDP, and $u_{i t}$ is an error term. According to economic theory ${ }^{28}$, elasticities $\beta_{2}$ and $\beta_{3}$ are expected to be negative, and $\beta_{j}$, and $\beta_{4}$ are expected to be positive. The import demand equations for New Zealand logs imported by Korea, Japan, and China were estimated separately.

New Zealand logs are used in different ways in dif-

$\uparrow$ Because we undertake analysis by separately considering Korea, Japan, and China, when specifying the log export supply function to one country, the prices for the other two countries became the prices for New Zealand log exports in alternative markets. ferent countries: for example, plywood manufacturing in Korea, furniture manufacturing in China, and small lumber manufacturing in Japan. GDP may affect the demand as a scale factor. As shown in the above two equations, various demand factors in different countries are simplified to the total production output, which is proxied by the country's GDP.

\section{Data}

Annual time series data from 1990 to 2008 were used for the analysis. 1990 was used as the starting point for the analysis because prior to this year Chinese production was still under a planned economy and New Zealand forests were largely under state ownership, where they were managed for non-timber objectives as well as for timber production.

All the data used for the log export supply equations, except for GDP, were from Statistics New Zealand ${ }^{33}$ and the Ministry of Agriculture and Forestry ${ }^{17}$. Demand data were from Korean, Japanese, and Chinese statistical agencies $^{33}$. GDP and GDP deflator data were from the World Bank ${ }^{32}$. The free-on-board (f.o.b.) price for New Zealand's exports was from Statistics New Zealand ${ }^{33}$, in New Zealand dollars, and the cost-insurance-freight (c.i.f.) prices $\$$ for imports by Korea, Japan, and China were from the respective governments. Chinese and Korean import prices were in U.S. dollars, and Japanese import prices were in units of 1,000 Japanese yen. When introduced into the model, price data were expressed in their respective local currency for each country. For China and Korea, price data in U.S. dollars were converted into Chinese yuan and Korean won, respectively.

From 1990 to 2008, New Zealand's log exports to Korea and China have increased in quantity by an average $4.7 \%$ per annum and $13.6 \%$ per annum, respectively. During the same period, log exports to Japan have experienced a steady decline of $3.0 \%$ per annum (Fig. 1). More recently, however, there has been a decline in export to Korea and a sharp increase to China. The large decline in log exports to Korea in 1998 was associated with the Asian economic crisis. The real prices received for New Zealand's log exports to China, Japan, and Korea are similar for all destinations (Fig. 2). From 1990 to 2008, the overall trend in real prices has been downward due to reduced global wood supply, though there was a large increase in prices in 1992 to 1994.

From 1990 to 2002, New Zealand's harvest volume increased steadily, averaging $4.0 \%$ per annum growth,

$\$$ The c.i.f. price is the selling price including the cost of the goods, the freight or transport costs, and the cost of marine insurance. 
with a single year of decline during the Asian economic crisis (Fig. 3). Since 2002, harvest volume has declined in line with the decline in log exports (Fig. 1). From 1990 to 2008, there has been steady growth in New Zealand's real GDP of an average $2.9 \%$ per annum, with a slight slowing in growth during the Asian economic crisis (Fig. $3)$.

From 1990 to 2002, the real price of log imports from New Zealand by China, Japan, and Korea declined. More recently the import price has increased in all three import markets (Fig. 4). The real price of log imports by China, Japan, and Korea from countries other than New Zealand have followed a similar trend to the price of New Zealand's log imports (Fig. 5).

Figure 6 shows the prices for New Zealand logs exported to Korea and imported in Korea in constant 2005

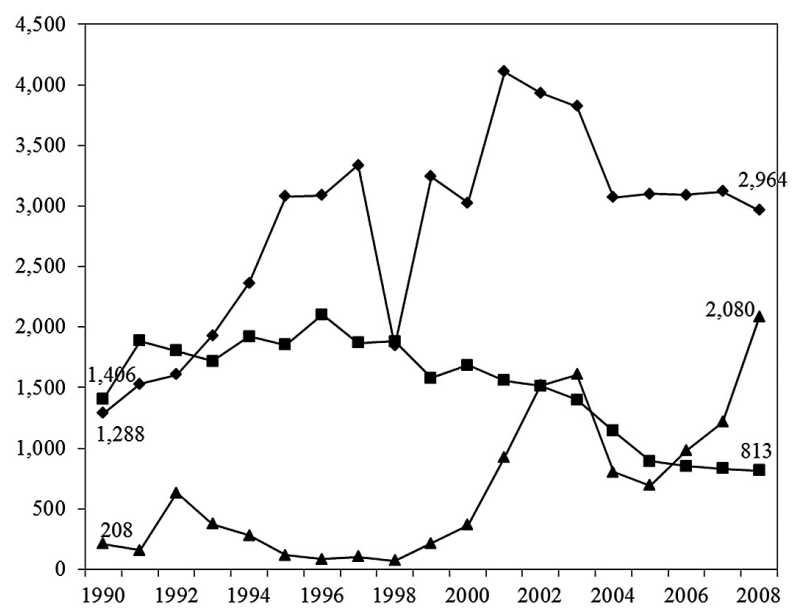

Fig. 1. New Zealand's log export volume, by destination $\left(000 \mathrm{~m}^{3}\right)$
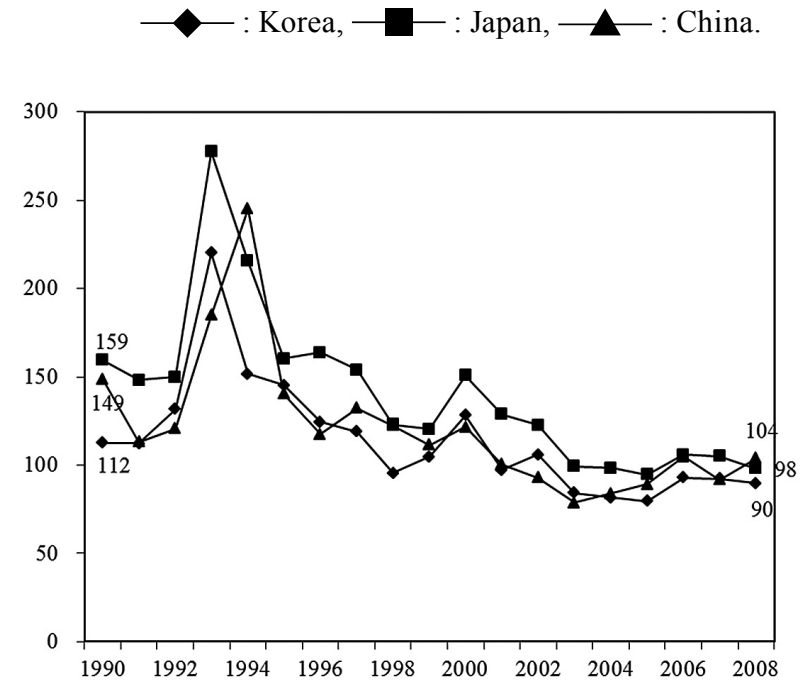

Fig. 2. Real price (2005 value) of New Zealand's log exports, by destination (NZ\$ f.o.b./ $\mathbf{m}^{3}$ )

: Korea, $\longrightarrow$ : Japan, $\longrightarrow$ : China.

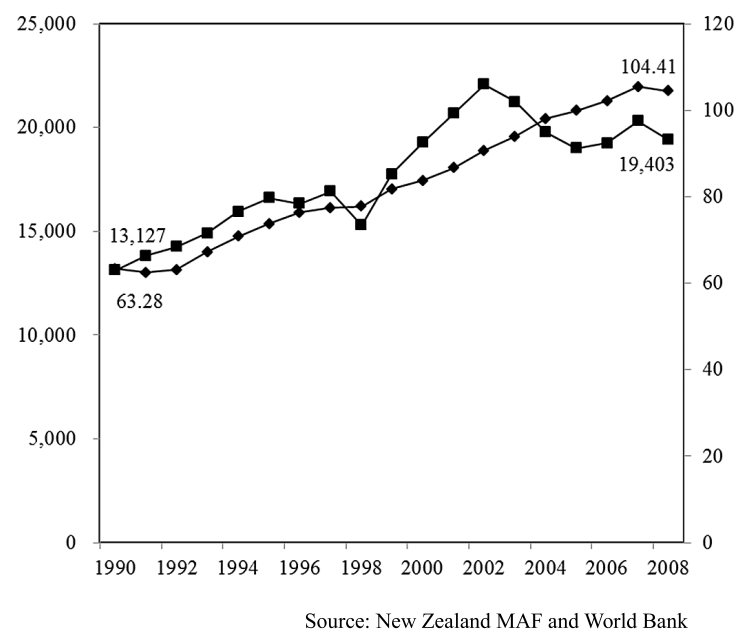

Fig. 3. New Zealand's log harvest volume (million $\mathbf{m}^{3}$ ) and New Zealand's real GDP (US\$ billion, 2005 value) —- Log Harvest, : NZ GDP (right axis).

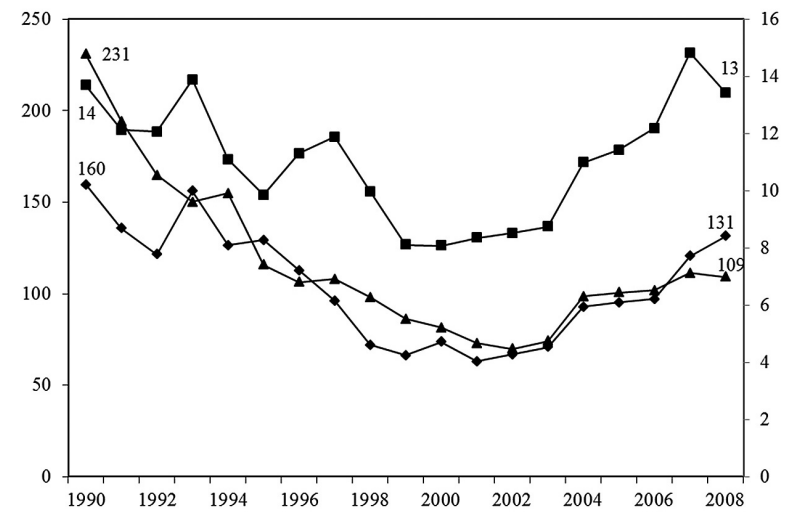

Fig. 4. Real import price (2005 value) of New Zealand logs, by importer

- : Korea (US\$), $\boldsymbol{\Delta}$ : China (US\$), — : Japan (000 Yen, right axis).

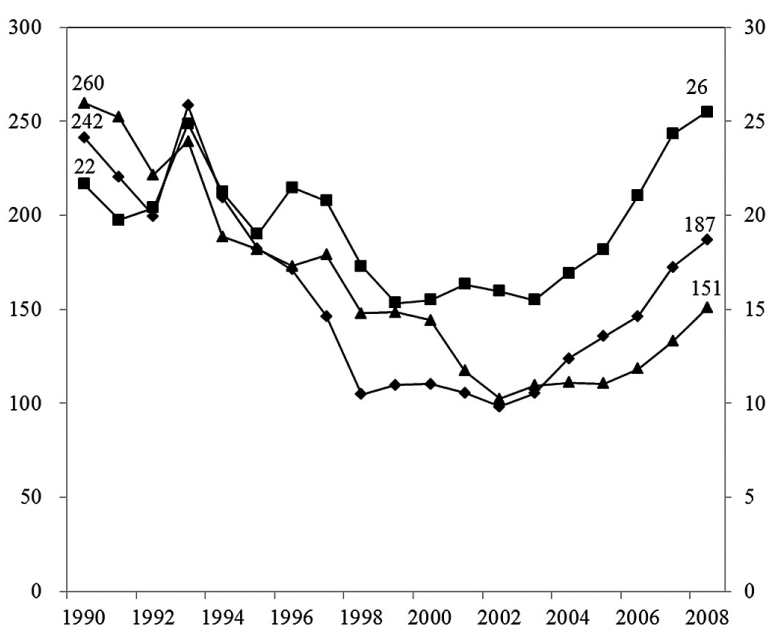

Fig. 5. Real import price (2005 value) of logs from exporters other than New Zealand, by importer

: Korea (US\$), $\longrightarrow$ : China (US\$), - - : Japan (000 Yen, right axis). 
U.S. dollars (the situations in Japan and China are similar to Korea). It can be seen that as the New Zealand dollar strengthens or weakens against the U.S. dollar, the price received in Korea (expressed in U.S. dollars) also strengthens or weakens. Since 2002, the New Zealand dollar has strengthened against the U.S. dollar, and oil prices have increased. As a result, the gap in prices between the import and export side has increased. The export price for New Zealand logs to East Asia spiked in 1993 due to the reduction in harvests from U.S. national forests and from Russia.

From 1990 to 2008, all three importing countries, China, Japan, and Korea, have experienced steady real economic growth (Fig. 7), though not unexpectedly growth has been strongest in China. Korea's economy grew on average $5.3 \%$ per annum, Japan's $1.2 \%$ per annum, and China's $10.2 \%$.

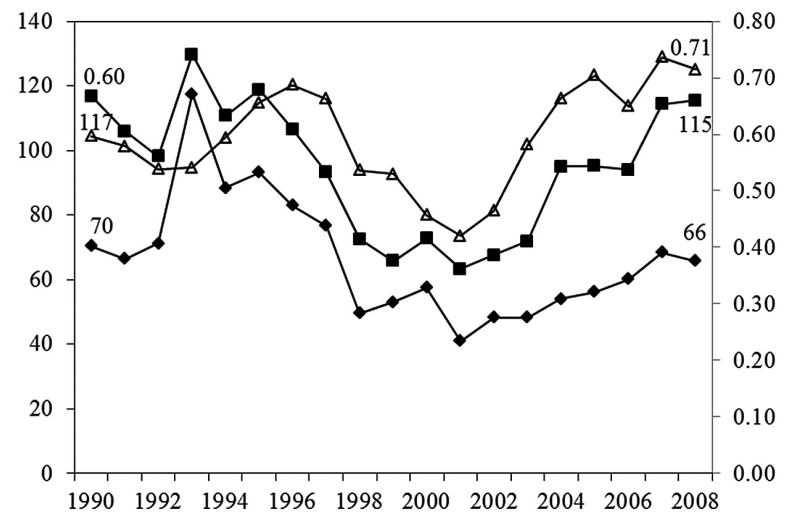

Fig. 6. Real prices of New Zealand logs exported to Korea and imported in Korea (2005 US dollars)

: NZ export to Korea (US\$),

—- : Korea import from NZ (US\$),

$\triangle$ : NZ dollar exchange rate (right axis, US\$).

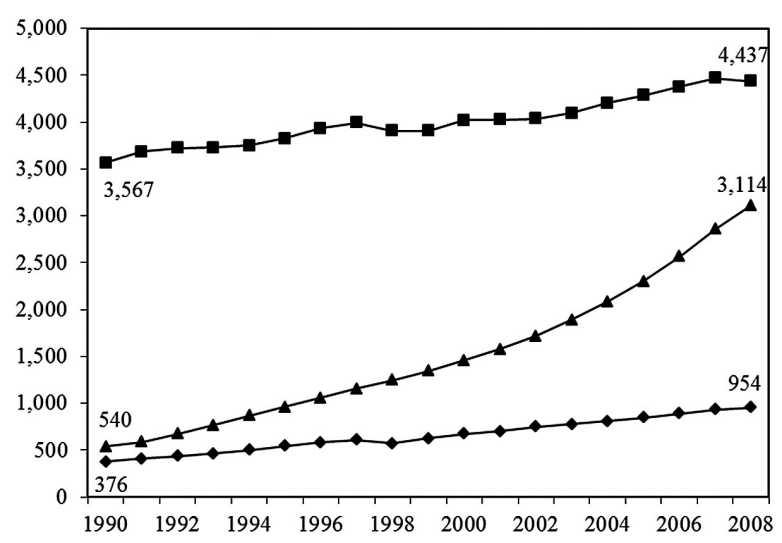

Fig. 7. GDP by importer (US\$ billion, 2005 value)

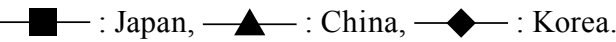

\section{Methods}

Due to the rising and unstable gap between f.o.b. prices on the supply side and c.i.f. prices on the demand side caused by rising oil prices since 2004 , and due to the unstable gap in quantity between the two sides given the period of log shipment from New Zealand to East Asian countries and measurement errors, equilibrium models were not estimated, while supply models and demand models were estimated separately. As it is known that OLS regression could give rise to biased estimates with autocorrelated errors, two-stage-least squares (2SLS) regression was applied in this research, using exogenous variables like GDP as instrumental variables in stepwise regression.

The stepwise regression works as follows: Dependent variables were firstly regressed against all independent variables. Variables with opposite to expected sign or low statistical significance (based on t ratios), except for the prices of supply and demand, were deleted and the function was re-estimated until reaching the final model. This method is widely used in many fields ${ }^{14}$ and has been used in previous studies estimating import demand and export supply ${ }^{22}$. Some research uses this approach to choose appropriate models ${ }^{22}$, while other research chooses appropriate variables by examining the sign and significance of coefficients in the equation ${ }^{14}$. The former pays attention to the whole model, while the latter pays attention to variables. In some research, stepwise regression is used to eliminate variables that do not influence variation in the model.

The criteria in the stepwise regression could be $\mathrm{t}, \mathrm{F}$, $\mathrm{R}^{2}$, Durbin Watson (DW) statistics, Akaike Information Criterion (AIC), RMSE (root mean square error), MAE (mean absolute error) ${ }^{13}$, etc. In this research, the specifications of model variables are based on a combination of significance level, sign, and Durbin Watson statistics. Empirical estimations here are based on assuming cost minimization under a generalized Cobb-Douglas production function. In some situations, however, an opposite sign of coefficient might be caused by misspecification. As we want to find significant factors that affect supply and demand, it is good to revise the models by adopting a stepwise regression approach.

The final models from stepwise regression were tested for autocorrelated errors using the Durbin-Watson (DW) statistics ${ }^{31}$. For the purpose of correction to error terms and to give efficient estimates, the final models were re-estimated using the maximum likelihood method with a first order autoregression [AR(1)] coefficient in the error term (for example, in the log export supply equation [1], $\varepsilon_{i t}=\mu_{t}-\rho \mu_{t-1}$, where $\rho$ is the autoregression coefficient $)^{31}$. One-year lagged own price and time trend 
were also introduced to reduce autocorrelation, but only significant one-year lagged own price and time trends remained in the final models.

A natural log-linear form for the export supply and import demand equations was used. Estimated coefficients therefore represent elasticities of the export supply and import demand with respect to model variables. For example, the coefficient on price in the New Zealand log export supply function describes the percentage change in export supply due to a $1 \%$ increase in price.

\section{Results and discussion}

\section{Export Supply Equations for New Zealand logs to Korea, Japan, and China}

Based on the log export supply equation (Equation [1]), the parameter estimates for the full model and final model selected by the step-wise regression are shown in Table 3.

All three final log export supply equations (Table 3) explain over $71 \%$ of the variability in the data, as shown by the coefficient of determination, $\mathrm{R}^{2}$. Autoregression coefficients are $0.222,0.709$, and 0.772 , respectively, for Korea, Japan, and China, and the autoregression coefficients in models for supply to Japan and China are significant as shown in the $t$ ratios for rho values. Because DW statistics are biased in AR(1), in which a lagged dependent variable is included, Durbin's h statistics are introduced in the test of autocorrelation to final models ${ }^{14}$. In these three AR(1) models for supply, Durbin's h statistics are not significant, indicating no autocorrelation.

The first two equations have small own price elasticities of supply, suggesting that New Zealand's export $\log$ supply to these countries is not price-responsive. This lack of price-responsiveness may be due to some exporters seeking a stable year-on-year cashflow. In fact, New Zealand's log export supply to Korea and China is more strongly influenced by New Zealand's harvest volume, with a highly elastic response. For log export supply to Japan, New Zealand's GDP has a negative impact on supply, suggesting that increased domestic activity diverts $\log$ exports away from the Japanese market. This is unexpected as Japan has traditionally used New Zealand radiata pine in the manufacture of plywood and packaging9 In the model of log export supply to China, the price response is elastic, which is different from the other two markets.

For all three log export supply equations the price of New Zealand logs in alternative log markets, i.e., in China and Japan for log exports to Korea, had no effect on exports. This suggests that these markets are viewed as being distinct for New Zealand's log exporters. This is

Table 3. Export supply equations for New Zealand logs to South Korea, Japan, and China: step-wise regression results

\begin{tabular}{|c|c|c|c|c|c|c|}
\hline \multirow[t]{2}{*}{ Item } & \multicolumn{2}{|c|}{ Korea } & \multicolumn{2}{|c|}{ Japan } & \multicolumn{2}{|c|}{ China } \\
\hline & 2SLS (1) & 2SLS (2) & 2SLS (1) & 2SLS (2) & 2SLS (1) & 2SLS (2) \\
\hline Own Price & $\begin{array}{c}1.274 \\
(0.844)\end{array}$ & $\begin{array}{c}0.494 \\
(1.756)^{*}\end{array}$ & $\begin{array}{l}-1.701 \\
(0.836)\end{array}$ & $\begin{array}{c}0.016 \\
(0.106)\end{array}$ & $\begin{array}{c}-1.559 \\
(-0.186)\end{array}$ & $\begin{array}{c}1.490 \\
(1.173)\end{array}$ \\
\hline Other price $\left(\mathrm{NZ} \$ / \mathrm{m}^{3}\right)$ & $\begin{array}{c}-1.170 \\
(-0.727)\end{array}$ & & $\begin{array}{c}0.606 \\
(0.898)\end{array}$ & & $\begin{array}{c}1.778 \\
(0.434)\end{array}$ & \\
\hline Other price ${ }^{+}\left(\mathrm{NZ} \$ / \mathrm{m}^{3}\right)$ & $\begin{array}{c}0.192 \\
(0.471)\end{array}$ & & $\begin{array}{c}1.051 \\
(0.719)\end{array}$ & & $\begin{array}{c}-0.515 \\
(-0.048)\end{array}$ & \\
\hline Log harvest $\left(000 \mathrm{~m}^{3}\right)$ & $\begin{array}{l}2.493 \\
(3.543)^{* * *}\end{array}$ & $\begin{array}{l}2.367 \\
(5.598)^{* * *}\end{array}$ & $\begin{array}{l}2.261 \\
(2.424)^{* *}\end{array}$ & $\begin{array}{c}0.474 \\
(1.119)\end{array}$ & $\begin{array}{c}1.963 \\
(0.248)\end{array}$ & $\begin{array}{l}6.302 \\
(2.196)^{* *}\end{array}$ \\
\hline GDP (US\$ billion) & $\begin{array}{c}-0.510 \\
(-0.642)\end{array}$ & & $\begin{array}{l}-3.624 \\
(-2.990)^{* * *}\end{array}$ & $\begin{array}{c}-2.689 \\
(-4.558)^{* * *}\end{array}$ & $\begin{array}{c}1.955 \\
(0.245)\end{array}$ & \\
\hline $\mathrm{R}^{2}$ & 0.712 & 0.768 & 0.680 & 0.925 & 0.485 & 0.715 \\
\hline $\mathrm{DW}$ or $\mathrm{DH}^{\circ}$ & 1.523 & $-0.92^{* *}$ & 1.541 & $-0.82^{* *}$ & 0.821 & $1.15^{* *}$ \\
\hline$\rho(\text { rho })^{\dagger}$ & & $\begin{array}{c}0.222 \\
(0.959)\end{array}$ & & $\begin{array}{l}0.709 \\
(5.800)^{* * *}\end{array}$ & & $\begin{array}{l}0.772 \\
(4.076)^{* * *}\end{array}$ \\
\hline
\end{tabular}

\footnotetext{
+ For export supply to Korea, other prices refer to Japan and China respectively; for Japan, other prices refer China and Korea respectively; for China, other prices refer Korea and Japan respectively.

Values in brackets are t ratios. ${ }^{* * *}$ : significant at $1 \%$ level; ${ }^{* *}$ : significant at $5 \%$ level; ${ }^{*}:$ significant at $10 \%$ level.

${ }^{\circ}$ DW: Durbin-Watson statistic for 2SLS(1); DH: Durbin's h statistic for 2SLS(2) ${ }^{14}$; ${ }^{* *}$ indicating no autocorrelation at $1 \%$ level; else the DW statistic is between the lower and upper bounds.

${ }^{\dagger} \rho\left(\right.$ rho): autoregression coefficient. Values in brackets are $t$ ratios. ${ }^{* * *}$ : significant at $1 \%$ level; others are not significant.
} 
perhaps due to the different uses of New Zealand radiata pine in these three markets 9 .

\section{Import Demand Equations for New Zealand Logs in Korea, Japan and China}

Based on the log import demand equation (Equation [2]), the parameter estimates for the full model and final model selected by the step-wise regression are shown in Table 4.

The final log import demand equations (Table 4) explain over $72 \%$ of the variability in the data for the three markets, as shown by the coefficient of determination, $\mathrm{R}^{2}$. The price elasticities in all three equations have the expected negative sign. The import demand response is elastic to price changes in Japan, but not elastic in Korea and China. The price of logs from other countries than from New Zealand affects demand for New Zealand logs in Japan, but it does not affect the demand for New Zealand logs in Korea and China. GDP growth in these three markets impacts on the demand for New Zealand logs, though the impact in Japan and China is strong while it is modest in Korea. Autoregression coefficients are 0.273, 0.197, and 0.703, respectively, for Korea, Japan, and China, but only the autoregression coefficient in the model for demand in China is significant. Durbin's h statistics in the final AR(1) models show that the models for demand for New Zealand logs in both Korea and China have no autocorrelation, while the autocorrelation issue is not clear for demand in Japan due to the limitation of Durbin's $\mathrm{h}$ statistics. Time trend in Japan import demand model is significant and negative, showing demand in Japan has been decreasing over time.

A possible reason for Korean imports of New Zealand logs being inelastic to GDP is a decline in Korea's dependency on imported logs and overall demand for wood. Korea's domestic supply of logs has increased rapidly, from 1.1 million $\mathrm{m}^{3}$ in 2000 to 2.1 million $\mathrm{m}^{3}$ in $2005^{11}$. As a consequence, Korea's self-sufficiency in timber (the ratio of production to consumption) has increased from about $12 \%$ at the beginning of the 1990 s to about $24 \%$ in $2004^{12}$.

The final Japan import demand equation (Table 4) has a high and significant price elasticity, showing that the demand for New Zealand logs is price-sensitive. Japanese demand for New Zealand logs is strongly affected by GDP. As Japan's economy grows slowly, even having a negative growth in some years, the demand for New Zealand logs is also affected.

Table 4. Import demand equations for New Zealand logs to South Korea, Japan and China: step-wise regression results

\begin{tabular}{|c|c|c|c|c|c|c|}
\hline \multirow[t]{2}{*}{ Item } & \multicolumn{2}{|c|}{ Korea } & \multicolumn{2}{|c|}{ Japan } & \multicolumn{2}{|c|}{ China } \\
\hline & 2SLS (1) & $2 \operatorname{SLS}(2)$ & 2SLS (1) & 2SLS (2) & 2SLS (1) & 2SLS (2) \\
\hline $\begin{array}{l}\text { Own price } \\
\left(\text { currency }^{+} / \mathrm{m}^{3}\right)\end{array}$ & $\begin{array}{l}-5.636 \\
(-1.587)\end{array}$ & $\begin{array}{l}-0.641 \\
(-2.992)\end{array}$ & $\begin{array}{c}-2.211 \\
(-2.404)\end{array}$ & $\begin{array}{l}-2.665 \\
(-2.897)^{* * *}\end{array}$ & $\begin{array}{l}-0.690 \\
(-0.385)\end{array}$ & $\begin{array}{l}-0.742 \\
(-1.178)\end{array}$ \\
\hline $\begin{array}{l}\text { One-year lagged } \\
\text { own price }\end{array}$ & & & & & & $\begin{array}{c}-2.945 \\
(-6.696)\end{array}$ \\
\hline TIME & & & & $\begin{array}{l}-0.132 \\
(-2.926)^{* * *}\end{array}$ & & \\
\hline Other Price & $\begin{array}{l}4.907 \\
(1.367)\end{array}$ & & $\begin{array}{l}1.865 \\
(1.836)\end{array}$ & $\begin{array}{l}1.726 \\
(2.074)^{* *}\end{array}$ & $\begin{array}{c}-3.232 \\
(-2.058)\end{array}$ & \\
\hline GDP (US\$ billion) & $\begin{array}{l}1.559 \\
(2.914)\end{array}$ & $\begin{array}{c}0.702 \\
(3.795)\end{array}$ & $\begin{array}{c}-3.537 \\
(-5.470)\end{array}$ & $\begin{array}{c}7.679 \\
(1.839)^{*}\end{array}$ & $\begin{array}{c}0.258 \\
(0.606)\end{array}$ & $\begin{array}{l}2.831 \\
(3.084)^{* * *}\end{array}$ \\
\hline $\mathrm{R}^{2}$ & 0.569 & 0.729 & 0.750 & 0.850 & 0.672 & 0.943 \\
\hline $\mathrm{DW}^{\circ}$ & $1.945^{* *}$ & $-0.39^{* *}$ & 1.438 & N.A. & 1.204 & $-0.23^{* *}$ \\
\hline$\rho(\text { rho })^{\dagger}$ & & $\begin{array}{c}0.283 \\
(1.507)\end{array}$ & & $\begin{array}{c}0.197 \\
(0.773)\end{array}$ & & $\begin{array}{l}0.703 \\
(7.092)^{* * *}\end{array}$ \\
\hline
\end{tabular}

Values in brackets are t ratios. ${ }^{* * *}$ : significant at $1 \%$ level; ${ }^{* *}$ : significant at $5 \%$ level; ${ }^{*}:$ significant at $10 \%$ level.

${ }^{+}$For China and South Korea the currency is US dollars. For Japan the currency is 000 Yen.

'DW: Durbin-Watson statistic for 2SLS(1); DH: Durbin's h statistic for 2SLS(2) ${ }^{14}$; **: indicating no autocorrelation at $1 \%$ level; else the DW statistic is between the lower and upper bounds.

${ }^{2}$ Durbin's h statistic cannot be computed here because the estimated variance of the least squares regression coefficient on $M_{j p, t-1}$ is larger than $1 / \mathrm{n}$.

$\dagger \rho\left(\right.$ rho): autoregression coefficient. Values in brackets are $t$ ratios. ${ }^{* * *}$ : significant at $1 \%$ level; others are not significant. 
The final equation of Chinese log import demand (Table 4) shows a negative effect of log import price, with a strongly elastic response to the one-year lagged price. This result agrees with previous studies of import demand for New Zealand logs in China, Japan, and Korea ${ }^{10}$. China's GDP was found to influence its demand for New Zealand logs (Table 4). China's demand for logs is mainly for use in export products. The policy of rebates of valueadded-tax for exporters has played an important role in the latter ${ }^{35}$. China's wood and wood products (HS Code $44^{\S}$ ) imports are mainly logs and sawn timber, accounting for $83 \%$ of import value in 2005 , while exports are mainly processed products. An important driver of China's demand for New Zealand radiata pine is its production and export of plywood ${ }^{9,3,19}$, due to the quality of plywood that uses New Zealand radiata pine as a core. Exports of plywood increased from 0.4 million $\mathrm{m}^{3}$ in 1999 to 8.3 million $\mathrm{m}^{3}$ in 2006. Using radiata pine also conforms to the requirements for environmental certification in Europe and North America, such as CE and FSC certification. Some operators have already been offering small volumes of FSC-certified plywood in China?. The strong negative effect of price on China's import demand (Table 4) suggests that the relatively higher cost of New Zealand logs has a stronger influence on China's demand for New Zealand logs.

\section{Conclusions}

This study estimated export supply and import demand equations for New Zealand logs in Korea, Japan, and China, with the intent of identifying important influences on this trade. For New Zealand's log export supply in Korea and Japan price responses are inelastic, i.e., changes in log price have a small positive effect on supply, but the supply to China is price-responsive. The price of New Zealand logs in other export markets was found to have no effect on the exports to each other. This suggests that there is little competition for log exports to Korea, Japan, and China. New Zealand's total harvest was found to be a more important influence than price on New Zealand's log exports to Korea and China. New Zealand's domestic consumption of logs was found to compete with log exports to Japan, but not with exports to Korea or China.

Current log prices in Japan and one-year lagged price in China were found to be an important negative in-

$\S$ HS Code: code for Harmonized Commodity Description and Coding System. HS Code 44: wood and articles of wood; wood charcoal, including fuel wood, wood charcoal, wood in the rough, sawnwood, and wood panels. fluence on import demand for New Zealand logs, while it was inelastic to current log prices in Korea and China. China's log import demand was found to be especially responsive to one-year lagged price suggesting that the impacts of changes in price on China's demand for New Zealand logs emerges more in the next year. The reason for this result is not clear. GDP growth is a driver of demand for New Zealand logs. The demand is affected by GDP growth the most in Japan and the least in Korea.

This study tried to elucidate the trade market of an important forest product by econometric analysis. However, the models were selected and estimated for export and import separately due to some statistical constraints. Thus, the conclusions that were introduced from the results may not be consistent if the trade market is seen as an interactive behavior between exporters and importers. This point provides room for future improvement of this study.

\section{Acknowledgments}

Field surveys in New Zealand, Korea, and Japan, which led to this paper, were undertaken with funding from the Japanese Ministry of Education, Culture, Sports, Science and Technology Grants-in-Aid. The research leading to this paper was also supported in part by the New Zealand Forest Research Institute Ltd., trading as Scion.

\section{References}

1. Brown, C. (1997) In Depth Country Study - New Zealand. Asia-Pacific Forestry Sector Outlook Study. Working Paper series, Working Paper No: APFSOS/WP/05. FAO Forestry Planning and Statistics Branch, Rome.

2. Buongiorno, et al. (2003) The Global Forest Products Model: Structure, Estimation and Applications. Academic Press, San Diego, pp.301.

3. Chen, S.H. (2004) Radiata pine has become one of main import timber species in China. China Wood-Based Panels 110 (1), 26-27 [In Chinese].

4. CIBC World Markets (CIBC) (2007) Russia Plans to Dramatically Increase its Export Tax on Logs. CIBC World Markets, Equity Research Industry Update.

5. Chou, J.-J. \& Buongiorno, J. (1984) Demand functions for United States forest product exports to the European Economic Community. Wood and Fiber Science 16, 158-168.

6. FOA (New Zealand Forest Owners Association Inc.), WPA (Wood Processing Association on NZ) and MAF (Ministry of Agriculture and Forestry) (2007) New Zealand Forest Industry Facts and Figures - 2006/2007. New Zealand Forest Owners Association, Wellington.

7. International Tropical Timber Organisation (ITTO) (2008) Tropical Timber Market Report. 13 (3), 11.

8. Katz, A. (1988) A model of Pacific Rim log and lumber 
markets: Structure and projections. A thesis submitted to Oregon State University in partial fulfilment of the requirements for the degree of Doctor of Philosophy, pp.198.

9. Katz, A. (2004) Log export markets and their log requirements. New Zealand J. Forestry 49 (1), 21-25.

10. Katz, A. (2006) Wood supply to 2025 issues and opportunities: An application of the radiata pine market model. May 2006, pers. comm. Alphametrik, New Zealand.

11. Korea Forest Research Institute (KFRI) (2006) Quarterly Report on Forestry Economy 1st Quarter 2006, Seoul, pp.88 [In Korean].

12. Korea Forest Service (KFS) (2005) Statistical Yearbook of Forestry, Seoul, pp.462 [In Korean].

13. Liu, C. \& Zhang, S. Y. (2005) Models for predicting product recovery using selected tree characteristics of black spruce. Canadian J. Forest Research, 35 (4), 930-937.

14. Maddala, G.S. (2001) Introduction to Econometrics, $3^{\text {rd }}$ ed., John Wiley, New Jersey, pp.664.

15. Magee, Stephen P. (1975) Prices, Income and Foreign Trade: A Survey of Recent Economic Studies, in P.B. Kenen (ed.), International Trade and Finance: Frontiers for Research, Cambridge University Press, 175-252.

16. Manurung, E.G.T. \& Buongiorno, J. (1997) Effects of the ban on tropical log exports on the forestry sector of Indonesia. J. World Forest Resource Management 8, 21-49.

17. Ministry of Agriculture and Forestry (MAF) (1997) New Zealand's Forest Growing and Wood Processing Sector: Regional Studies: Central North Island. New Zealand Ministry of Agriculture and Forestry, Wellington.

18. Ministry of Agriculture and Forestry (MAF) (2009) New Zealand Ministry of Agriculture and Forestry, Wellington. http://www.maf.govt.nz/forestry/.

19. Ogle, A. \& Miller, R. (2000) Wood supply and demand issues in the Pacific Rim - background situation. New Zealand J. Forestry 45 (3), 22-26.

20. Qin, Y. (2007) More imports, with higher price-Analysis on China's timber in 2006, International Wood Industry 4, 18-22 [In Chinese].

21. Sohngen, B. \& Sedjo, R. (1999) The potential role of plantations in the future timber supply. Resources for the Future, Washington, DC, pp.19.

22. Sutton, W.R.J. (1998) Will there be a demand for radiata pine in the future? New Zealand J. Forestry 43 (2), 19-25.

23. Thursby, J. \& Thursby, M. (1984) How reliable are simple single equation specifications of import demand? Review of Economics and Statistics 66, 120-128.

24. Tomberlin, D. (1999) Timber Supply, Trade, and Environment in the Pacific Rim Forest Sector. Unpublished $\mathrm{PhD}$ dissertation, University of Wisconsin, Madison.

25. Turner, J.A. \& Buongiorno, J. (2004) Estimating price and income elasticities of demand for imports of forest products from panel data. Scandinavian J. Forest Research 19 (4), 358-373.

26. Turner, J.A., Katz, A. \& Buongiorno, J. (2007) Implications for the New Zealand wood products sector of trade distortions due to illegal logging. A report prepared for MAF by Scion. Scion, Rotorua. www.maf.govt.nz/forestry/illegallogging/trade-distortion-implications/index.htm.

27. Turner, et al. (2008) Implications of the Russian softwood log export tax for the Russian and global wood products sectors. Scandinavian J. Forest Research 23 (2), 154-166.

28. USDA Foreign Agricultural Service (USDA FAS) (2006) Malaysia: Solid Wood Products. GAIN Report MY6022. http://www.fas.usda.gov/gainfiles/200607/146208292.pdf.

29. Varian, H. R. (1992) Microeconomic analysis. Third edition. Norton, New York, NY. pp. 506.

30. Whiteman, A. \& Brown, C. (2000) Modelling global forest products supply and demand: recent results from FAO and their potential implications for New Zealand. New Zealand J. Forestry 44 (4), 6-9.

31. Wijewardana, D. (2005) Market perspectives for timber planted forests. New Zealand J. Forestry 50 (1), 34-41.

32. Wooldridge, J.M. (2000) Introduction to Econometrics: A Modern Approach. (1 ${ }^{\text {st }}$ ed.) Mason, OH: Thomson SouthWestern, pp.824.

33. World Bank (2009) World Development Indicators/Worldview, People, Environment, Economy, States and Markets, Global Links. Washington, DC.

34. World Trade Atlas (WTA) (2009) World Trade Atlas Trade Information System: New Zealand Edition, South Korea Edition, Japan Edition, and China Edition. Global Trade Information Services, Inc., Columbia, SC.

35. Youn, Y-C. (1998) Chapter 2: Korean timber markets and policy. In $3^{\text {rd }}$ IGES International Workshop on Forest Conservation Strategies for the Asia and Pacific Region, September 7-9, 1999. www.iges.or.jp/en/fc/phase1/ir98-4-4. pdf.

36. Zhang, Y., Tachibana, S. \& Nagata, S. (2007) Trend of China's trade in forest products under the socialist market economy, Forest Economy 702, 1-16 [In Japanese]. 